Article

\title{
Social Capital and Organizational Citizenship Behavior: Double-Mediation of Emotional Regulation and Job Engagement
}

\author{
Sung-Hoon Ko ${ }^{1}$, Yongjun Choi ${ }^{2, *}$, Seung-Yoon Rhee ${ }^{2} \mathbb{D}$ and Tae Won Moon ${ }^{2}$ \\ 1 School of Business, Kyungpook National University, Daegu 41566, Korea; sunghoonko7@gmail.com \\ 2 College of Business Administration, Hongik University, Seoul 04066, Korea; syrhee@hongik.ac.kr (S.-Y.R.); \\ twmoon@hongik.ac.kr (T.W.M.) \\ * Correspondence: yongjun.choi@hongik.ac.kr; Tel.: +82-2-320-1735
}

Received: 12 September 2018; Accepted: 8 October 2018; Published: 10 October 2018

check for updates

\begin{abstract}
Despite an enduring interest in emotional labor, the effects of social capital on the emotional regulation process remain relatively underexplored. Using the job demands-resources model, we propose that social capital provides employees with the job resources required for deep acting. We also propose a double-mediation effect of deep or surface acting and job engagement, through which employee social capital can increase organizational citizenship behavior (OCB). Empirical results using data from 330 employees selling financial or insurance products in South Korea support our hypotheses that deep acting by sales employees and job engagement sequentially mediate the positive relationship between social capital and OCB.
\end{abstract}

Keywords: emotional labor; social capital; job demands-resources model; job engagement; organizational citizenship behaviors

\section{Introduction}

Social capital, "a quality created between people" [1] (p. 339), in the workplace is integral for employees' organizational lives [2,3] because it serves as important assets for their success at work $[2,4,5]$ through the quality exchange of knowledge and information with others [6,7]. Especially, studies showed that, beyond task performance, it increases employees' contextual performance, such as organizational citizenship behavior (OCB) [8-10], because frequent quality interactions with others increase one's willingness as well as sense of responsibility to engage in such behaviors $[4,8,10]$. Hence, given that OCB is critical for sustainable workplaces [11], it is important for organizations to understand how and why social capital influences employees OCB. However, less is known about why, and through what mechanisms, this relationship exists. In addition, while exploring the relationships between social capital and OCB, despite its importance in understanding employees' behaviors [12], relatively less attention has been paid to the roles of context in the literature. Hence, in this study, we aim at exploring the mechanism underlying the effects of social capital on OCB in the emotional labor context.

Emotional labor is defined as "the act of displaying appropriate emotion (i.e., conforming to a display rule)" [13] (p. 90). It is one of the core components of occupations involving high levels of customer interaction [14-17]. Despite being an integral part of service-oriented work, emotional labor can deplete one's resources, as employees must manage their emotions to fulfill their job requirements. Such resource loss can lead to negative work outcomes, including emotional exhaustion [18-20]. If the organization fails to manage emotional exhaustion effectively, it will incur high costs as a result of poor work performance and high employee turnover [21]. Thus, from an organization's perspective, 
understanding emotional labor and helping its employees cope with work pressures (especially service employees) is critical for building a sustainable workplace [20,22].

Theories on emotional labor suggest that while regulating their emotions, employees use one of two techniques: surface acting (where actors follow the required rules of emotional display without expressing their true inner feelings) and deep acting (where actors attempt to modify their actual feelings to correspond to the rules of emotional display) $[13,18]$. Previous studies largely support the idea that while surface acting is detrimental to job attitudes and psychological well-being, deep acting increases job performance and customer satisfaction [23,24]. Accordingly, researchers have explored factors that influence employee choice of emotional regulation strategies. Research indicates that individual differences $[20,25-27]$ and perceptions of the rules of emotional display $[18,27]$ tend to shape employees' choice of surface or deep acting.

The impact of job resources on emotion regulation in service contexts is relatively less known. Job resources are important for employees dealing with high job demands [28-30]. By helping employees manage their emotions better, job resources can enable them to achieve their work objectives. A recent study by Yoo and Arnold [31] provides evidence of how job resources affect one's choice of emotional regulation strategies by showing that perceived organizational support facilitates the use of deep acting.

Drawing upon the job demands-resources (JD-R) model [28-30], we aim at examining the roles of job resources on the contextual performance in the emotion regulation process. To do so, we develop a model that explains how job resources can affect deep or surface acting and, ultimately, impact their contextual performance, that is, OCB. We focus on the roles of social capital as critical job resources [6,32] that help employees resolve task-related challenges through knowledge exchange [4] and help them gain and build trust with other members of the organization [33]. We argue that the social capital of sales employees can facilitate their OCB by providing job resources to deal with emotional demands better, and increase their job engagement. To date, no studies have empirically examined the impacts of social capital on the emotional regulation of service employees, and how such effects ultimately influence sales employees' OCB.

We seek to advance our current knowledge in several ways. First, we examine the roles of social capital as job resources in the emotional labor context. Although the benefits of social capital at work are well established [2,34], empirical knowledge is fairly scant when it comes to its effects in the emotional labor context. Thus, by highlighting the roles of social capital in understanding emotional regulation of service employees, we aim to provide organizations with insights to create sustainable workplaces. Second, building upon the previous empirical findings from the literature on social capital, emotional labor, and OCB, we explore how the social capital of sales employees affects their OCB through the double-mediation effects of emotional regulation techniques and job engagement. In doing so, we advance the literature by explaining the unexplored mechanisms underlying the effects of social capital on OCB in the emotional labor context. Finally, we examine the OCB of sales employees as the focal outcome of our model. Although OCB is a contextual performance that is equally important to task performance [3], except for a few studies [35,36], it has received relatively scant attention in the literature on emotional labor. In addition, given the well-established benefits of OCB on the individual-level (e.g., performance and turnover intentions) and organizational-level (e.g., productivity and, efficiency) outcomes [37,38], OCB is deemed crucial for sustainability [22]. Hence, by exploring $O C B$ as a focal outcome of social capital and emotional regulation in our model, we add new empirical insights into the literature on emotional labor and sustainability management.

\section{Hypotheses Development}

\subsection{JD-R Model}

The JD-R model [28-30] highlights two aspects of working conditions. First, job demands represent the job characteristics (physical, social, or organizational) that can potentially lead to strain 
reactions [39]. Second, job resources such as autonomy represent aspects that can energize work motivation and increase adaptive behaviors [30,40]. Job resources "(1) reduce job demands and the associated physiological and psychological costs; (2) are functional in achieving work goals; (3) stimulate personal growth, learning, and development" [39] (p. 395). Since job demands drain an employee's energy while job resources trigger their motivational processes, employees should have adequate job resources for better performance [39].

It is noteworthy that the JD-R model and Hobfoll's [41] conservation of resources (COR) theory share many of the main arguments [28,42-44]. Indeed, the JD-R model (e.g., [39,45,46]) and the COR theory (e.g., $[19,31])$ were applied in a large body of studies on emotional labor. However, the JD-R model expands the COR theory, which has mostly been applied in stress literature at large [44,47]. It integrates the motivational perspective with the stress research tradition. According to the JD-R model, whereas job demands inhibit one's psychological health process, job resources trigger their motivational process $[28,42,48]$. Since our study focuses on social capital as job resources improving one's motivational state (i.e., job engagement) and adaptive behaviors (i.e., OCB), we developed our hypotheses using the JD-R model.

\subsection{Social Capital and Emotional Labor}

Emotional labor involves an individual's effort to modify or suppress his or her emotions during customer interaction to conform to the rules of emotional display [13-18]. Thus, it is a necessity for service employees who frequently interact with customers as part of their jobs [13]. Emotional labor is usually considered a job stressor $[25,26]$ because employees' emotional autonomy, in terms of expressing their emotions, becomes limited. Service employees therefore need to invest in appropriate resources to manage their emotions better $[26,39,45,46]$.

Service employees use resources to perform both surface and deep acting [49-51]. However, deep acting requires more resources. While surface acting merely involves the modification of employees' facial expressions so that they are consistent with the rules of emotional display, deep acting requires them to shape their true feelings and indulge in feelings that are consistent with the rules of emotional display. Research indicates that whereas surface acting leads to lower performance [52], greater emotional exhaustion [19,51-54], and high turnover intention [54], deep acting results in less emotional exhaustion [18] and a decrease in turnover intentions [53]. Deep acting also increases service performance because it produces emotional experiences that are perceived as sincere by customers [55]. Hence, to establish a sustainable workplace as well as to increase employee sustainability, organizations should encourage their employees to exhibit deep acting.

Job resources are critical for employees to cope with job demands better, because it is highly likely that employees with such resources will go beyond mere goal accomplishment [56]. Thus, in the emotional labor context, to handle emotional labor demands better, service employees need appropriate resources that would allow them to perform deep acting. Among the various resources, prior studies on emotional labor have mostly emphasized the importance of an individual's emotional resources $[26,57,58]$. The roles of job resources have gained increasing attention in the literature on emotional labor. For example, recent studies have showed that autonomy and social support are associated with extra-role performance via the disengagement aspect of burnout [29]. In addition, perceived organizational support facilitates the use of deep acting [31]. However, empirical evidence regarding the roles of various forms of job resources in the emotional labor context is still limited.

We argue that social capital, as job resources, will provide employees with resources to encourage the use of deep acting. Job resources can be located at several levels: interpersonal relations, organizations, work, and task [28]. Social capital, "a quality created between people" [1] (p. 339), is the web of cooperative relationships created to achieve the common goals of the organization with which individuals are affiliated and refers to any utilizable capital from this relationship or structure $[59,60]$. It can function as a job resource as it represents the features of social relationships, interactions, and information sharing among organizational members through informal networks [6,32]. Social capital 
has been captured using three dimensions: structural, relational and cognitive [61]. Structural aspect of social capital focuses on the extent to which individuals are connected to each other and the interaction frequency, which has potential to create or hamper opportunities to access knowledge or resources. Social capital from a relational perspective emphasizes the emotional quality of relationships including trust, cohesiveness and emotional bond. Finally, cognitive dimension of social capital refers to a shared belief or value system, which fosters organizational functioning through shared goals and vision among the members. In this study, we take the three perspectives in developing our hypotheses. More specifically, we argue that social capital works as a job resource by creating opportunities to obtain knowledge and information, by strengthening the feeling of trust and cohesiveness, and by encouraging goal- and vision-sharing.

Social capital allows employees to exchange their knowledge and information with other organizational members [6,7]. Such knowledge and information gained through social relationships serve as important job resources in helping employees fulfill their job requirements, understand the expectations of the organization [7,62], and produce positive outcomes. In particular, employees with strong social capital are better informed of the rules of emotional display, since they have better job resources, as well as visions and values of their organizations. This helps them modify their feelings to correspond to the rules of emotional display. Employees can also improve their service performance by integrating such customer-specific behaviors into their work roles and serving customers with their true selves [63]. Employees with such feelings of unification are very likely to be sincere while following the rules of emotional display [64]. That is, employees with strong social capital will immerse themselves in deep acting by expressing their sincere emotions consistently with the rules of emotional display resulting from a better understanding of the rules. On the other hand, employees with weak social capital tend to lack an understanding of the rules of emotional display and how these rules are associated with the visions and values of the organization. Thus, they are likely to perform surface acting through simple modifications of their outward emotional expression, without shaping their true inner feelings. Thus, we hypothesize as follows:

Hypothesis 1. Social capital is positively related to deep acting.

Hypothesis 2. Social capital is negatively related to surface acting.

\subsection{Social Capital and Job Engagement}

Job engagement is an individual's positive motivational state while approaching work [65]. Kahn [66] further defines it as a state of mind where organizational members connect themselves to their work roles. From the perspective of the JD-R model, job engagement represents the positive emotional state revealed through collections of necessary job resources and self-motivation [28]. Job resources can enhance job engagement due to their motivational potential [29,30]. Empirical studies largely indicate that employees with high job resources, such as autonomy $[29,67,68]$, social support [29,67,68], job control [69], and possibilities of professional development [29], show higher job engagement.

Social capital serves as an important means to provide employees with social support. Employees can have a broad range of social support, including informational, instrumental, and emotional support [70]. It helps employees not only have better access to information and resources necessary for completing their jobs, but also provides them better career sponsorship from other organizational members [71]. Employees who have strong social capital will interact with coworkers frequently, sharing their difficulties, providing and receiving help, and exchanging information on effective ways to deal with customers. Through these interactions, they are more likely to consider themselves as a valuable part of the organization and recognize the organization's commitment to them [72,73]. This will facilitate their job engagement. Hence, we hypothesize as follows: 
Hypothesis 3. Social capital is positively related to job engagement.

\subsection{Emotional Regulation and Job Engagement}

Modifying an individual's emotions to adhere to the rules of emotional display may impose a psychological cost on service employees [74] and causes the drainage of resources. The negative outcomes of emotional labor, such as emotional exhaustion [18-20], are mainly due to the discrepancy between what one actually feels and what one expresses outward, resulting in emotional dissonance and stress [25]. Owing to the high level of experienced emotional dissonance, employees using surface acting are very likely to suffer from emotional exhaustion. However, deep acting is likely to result in less emotional exhaustion stemming from a relatively lesser degree of emotional dissonance. Empirical evidence also supports the fact that compared to deep acting, surface acting leads to more emotional exhaustion [18].

Job engagement is similar to emotional exhaustion in that it indicates employees' well-being and motivation [75]. We expect emotional resources restored or depleted through deep or surface acting to influence job engagement. Deep acting has been associated with less emotional dissonance, which helps maintain or even restore one's emotional resources, leading to greater engagement [76]. Deep acting also enables service employees to feel authentic [26]. Similarly, customers can sense an employee's sincerity, which leads to quality reciprocal relationships [77]. Sustainable and authentic relationships built between the employee and customers can function as job resources activating a positive motivational process and resulting in increased job engagement [28]. On the other hand, surface acting increases one's emotional dissonance leading to the depletion of one's resources [26] and a sense of insincerity. Thus, surface acting is expected to decrease the degree of job engagement. An empirical study of Chinese government employees supports our predictions [78]. Thus, we hypothesize the following:

Hypothesis 4. Deep acting is positively related to job engagement.

Hypothesis 5. Surface acting is negatively related to job engagement.

\subsection{Job Engagement and $O C B$}

OCB refers to an employee's voluntary behaviors that benefit an organization though not always rewarded [79]. It includes caring for and helping colleagues, working more than expected for the benefit of the organization, and investing increased job efforts even when not required $[79,80]$. OCB, as contextual performance, is important because such discretionary behaviors facilitate task activities and processes, and contribute to organizational effectiveness [3,81].

Employee engagement represents an individual's discretionary effort [82] as well as a sense of energy $[66,83]$. Specifically, according to Kahn $[66,84]$, engagement is the devotion of the cognitive, emotional, and physical energy to one's job. It refers to the allocation and concentrated and consistent use of resources. Thus, because engaged employees are highly energized and motivated to go the extra-mile at work, they are more likely to increase their discretionary inputs by performing more OCB [29]. Empirical studies support the fact that employee engagement leads to OCB (e.g., [29,85-89]). Hence, we hypothesize as follows:

Hypothesis 6. Job engagement is positively related to OCB. 


\subsection{Double-Mediation Effects-Emotional Regulation and Job Engagement}

To the best of our knowledge, the roles of social capital in the emotional labor context have not been empirically explored so far. Although social capital facilitates employees' extra-role behaviors [8-10], relatively little is known about why or through what mechanisms they do so. In this study, we aim to understand how and why social capital leads to OCB by theorizing and empirically testing its mediating mechanisms.

We propose considering emotional regulation and job engagement function as dual-mediators of the positive link between social capital and OCB. First, we predict that employees with strong social capital will perform OCB through higher job engagement [29]. As suggested in our previous hypotheses, social capital provides employees with job resources to deal with customers better, thus leading to job engagement. Engaged employees tend to put in extra efforts toward their jobs with more enthusiasm and confidence [67] because they are more immersed in their jobs [90]. It is more than likely that engaged employees will perform OCB because they are better at recognizing various activities that benefit the organization and voluntarily execute those activities [88].

Second, in the context of emotional labor we argue that emotional labor tactics can provide more solid explanations of why such relationships exist. We have argued in our previous hypotheses that employees with weak social capital will exhibit surface acting. Surface acting involves expressing the required emotions toward customers while hiding one's inner feelings. It often results in emotional dissonance [18] and a heightened level of stress [25]. Such negative experiences may deplete resources followed by decreased job engagement, and, ultimately reduce the extent to which service employees perform OCB. In contrast, employees with strong social capital are equipped with job resources sufficient to engage in deep acting. By being emotionally authentic while interacting with customers, employees can maintain or restore energy and resources, leading them to be more engaged in their jobs which in turn facilitates OCB. A study by Rich, Lepine, and Crawford [88] corroborates our proposition by showing that employees who perceive greater organizational support exhibit increased task performance and OCB by investing their physical, cognitive, and emotional energy. Hence, we hypothesize as follows:

Hypothesis 7. The relationship between social capital and OCB is sequentially mediated by deep acting and job engagement.

Hypothesis 8. The relationship between social capital and $O C B$ is sequentially mediated by surface acting and job engagement.

\section{Method}

\subsection{Study Participants and Procedures}

We recruited our study participants with the help of an online professional research institute in South Korea. We focused on service employees potentially experiencing emotional labor. As a result, 330 participants selling financial or insurance products completed the online survey. The average age was 37.70 years (standard deviation $(\mathrm{SD})=8.91$ ), and their average tenure was 2.89 years $(\mathrm{SD}=1.36$ ). In the entire sample, $57.6 \%$ were male, and $68.8 \%$ had bachelor's degrees.

\subsection{Measures}

All survey measures in English were translated into Korean, per Brislin's [91] methods. In addition, we used a five-point Likert-type scale, ranging from $1=$ strongly disagree to $5=$ strongly agree, to measure our study variables. 


\subsubsection{Social Capital}

We used Biong and Ulvnes' [92] inventory to measure social capital. A sample item includes "I have close conversations about work with my coworkers" (Cronbach's $\alpha=0.89$ ).

\subsubsection{Emotional Regulation}

To assess emotional regulation, we used items from Diefendorff, Croyle, and Gosserand [27]. Sample items include "I put on an act in order to deal with customers in an appropriate way" for surface acting (Cronbach's $\alpha=0.87$ ) and "I try to actually experience the emotions that I must show to customers" for deep acting (Cronbach's $\alpha=0.87$ ).

\subsubsection{Job Engagement}

We used the instrument by Schaufeli, Bakker, and Salanova [93] to assess job engagement. Sample items are "I feel very enthusiastic about my job" and "I am proud of the work that I do" (Cronbach's $\alpha=0.91$ ).

\subsubsection{OCB}

We measured OCB using items from Niehoff and Moorman [94]. Sample items are "I help others who have heavy work loads" and "I take time to listen to coworkers' problems and worries" (Cronbach's $\alpha=0.81$ ).

\section{Results}

\subsection{Data Analysis}

First, we calculated the internal consistency among the reliabilities. We also conducted a confirmatory factor analysis (CFA) to evaluate the discriminant and the convergent validity of our study variables. First, Cronbach's $\alpha$ coefficients for all of our study variables were satisfactory, ranging from 0.81 to 0.91 [95]. Second, the CFA results were also satisfactory $\left(\chi^{2}=614.16, \mathrm{df}=314 ; p<0.001\right.$; $\mathrm{RMSEA}=0.05 ; \mathrm{RMR}=0.04 ; \mathrm{CFI}=0.94 ; \mathrm{TLI}=0.93$ ). Factor and item loadings in our measurement models all exceeded 0.62. Descriptive statistics, averaged variance extracted (AVE), and zero-order correlations among our study variables are reported in Table 1 . AVEs all exceeded 0.5, which provides evidence of the discriminant validity of our study variables [96].

Table 1. Means, standard deviations (SD), and zero-order correlations.

\begin{tabular}{llllllll}
\hline & Mean & SD & $\mathbf{1}$ & $\mathbf{2}$ & $\mathbf{3}$ & $\mathbf{4}$ & $\mathbf{5}$ \\
\hline 1. Social capital & 3.41 & 0.73 & $\mathbf{0 . 9 4}$ & & & & \\
2. Surface acting & 3.43 & 0.76 & -0.08 & $\mathbf{0 . 9 4}$ & & & \\
3. Deep acting & 3.70 & 0.57 & $0.39^{* *}$ & $-0.17^{* *}$ & $\mathbf{0 . 9 1}$ & & \\
4. Job engagement & 3.46 & 0.69 & $0.43^{* *}$ & -0.11 & $0.59^{* *}$ & $\mathbf{0 . 9 3}$ & \\
5. Organizational citizenship behavior & 3.58 & 0.55 & $0.60^{* *}$ & $-0.15^{* *}$ & $0.58^{* *}$ & $0.56^{* *}$ & $\mathbf{0 . 8 6}$ \\
\hline
\end{tabular}

Note: $N=330 ;{ }^{*} p<0.05 ;{ }^{* *} p<0.01$; the numbers along the diagonal are the square root of the averaged variance extracted (AVE).

\subsection{Common Method Bias}

To control the common method variance (CMV), following the remedies by Podsakoff and his colleagues [97], we conducted Harman's single-factor test. Using the exploratory factor analysis, we examined the factors and variances deduced from the un-rotated factor solution. The analysis identified five factors with an eigenvalue greater than 1 . Their variances were $36.89 \%, 12.98 \%, 7.57 \%$, $6.48 \%$, and $5.37 \%$. Since the test identifies more than one factor and the factor with the highest variance accounts for less than $50 \%$ of the total variance, we concluded that our study does not have any serious common method bias. 


\subsection{Hypotheses Testing}

Structural equations modeling results indicate that our model fits the data well $\left(\chi^{2}=2389.73\right.$, $\mathrm{df}=324 ; p<0.001 ; \mathrm{RMSEA}=0.05 ; \mathrm{RMR}=0.05 ; \mathrm{CFI}=0.95 ; \mathrm{TLI}=0.94$ ). Tables 2 and 3 (also illustrated in Figure 1) show the analysis results. As shown in Figure 1, all paths except for the path between social capital and surface acting were significant. As predicted in Hypothesis 1, social capital showed a positive relationship with deep acting $(b=0.36, p<0.001)$. However, Hypothesis 2 was not supported since the path from social capital to surface acting was insignificant $(b=-0.08, n . s$.). Supporting Hypothesis 3 , social capital significantly predicted job engagement $(b=0.38, p<0.001)$. In support of Hypotheses 4 and 5, our results indicate that surface acting showed a negative relationship with job engagement $(b=-0.10, p<0.05)$ while deep acting exhibited a positive one $(b=0.54, p<0.001)$. Furthermore, supporting Hypothesis 6 , job engagement was positively associated with OCB $(b=0.54$, $p<0.001)$.

For Hypotheses 7 and 8, we tested the double-mediation effect using bootstrapping procedures $[98,99]$, which allows us to examine the indirect effect via these two mediators in succession. We also controlled for study participants' gender, age, tenure, and education. Tables 2 and 3 report the indirect effects and 95\% bootstrapped confidence intervals (CIs). Table 2 indicates that social capital was positively associated with $\mathrm{OCB}$ via either deep acting (indirect effect $=0.08, \mathrm{SE}=0.02$, $\mathrm{CI}=[0.04,0.14])$ or job engagement (indirect effect $=0.04, \mathrm{SE}=0.01, \mathrm{CI}=[0.01,0.07])$. In addition, social capital had a positive relationship with $\mathrm{OCB}$, sequentially mediated by deep acting and job engagement (indirect effect $=0.03, \mathrm{SE}=0.01, \mathrm{CI}=[0.01,0.05]$ ). Specifically, the bootstrapping results indicate that deep acting and job engagement partially double-mediated the relationship between social capital and OCB since the direct effect of social capital on OCB was also significant. Hence, Hypothesis 7 was supported.

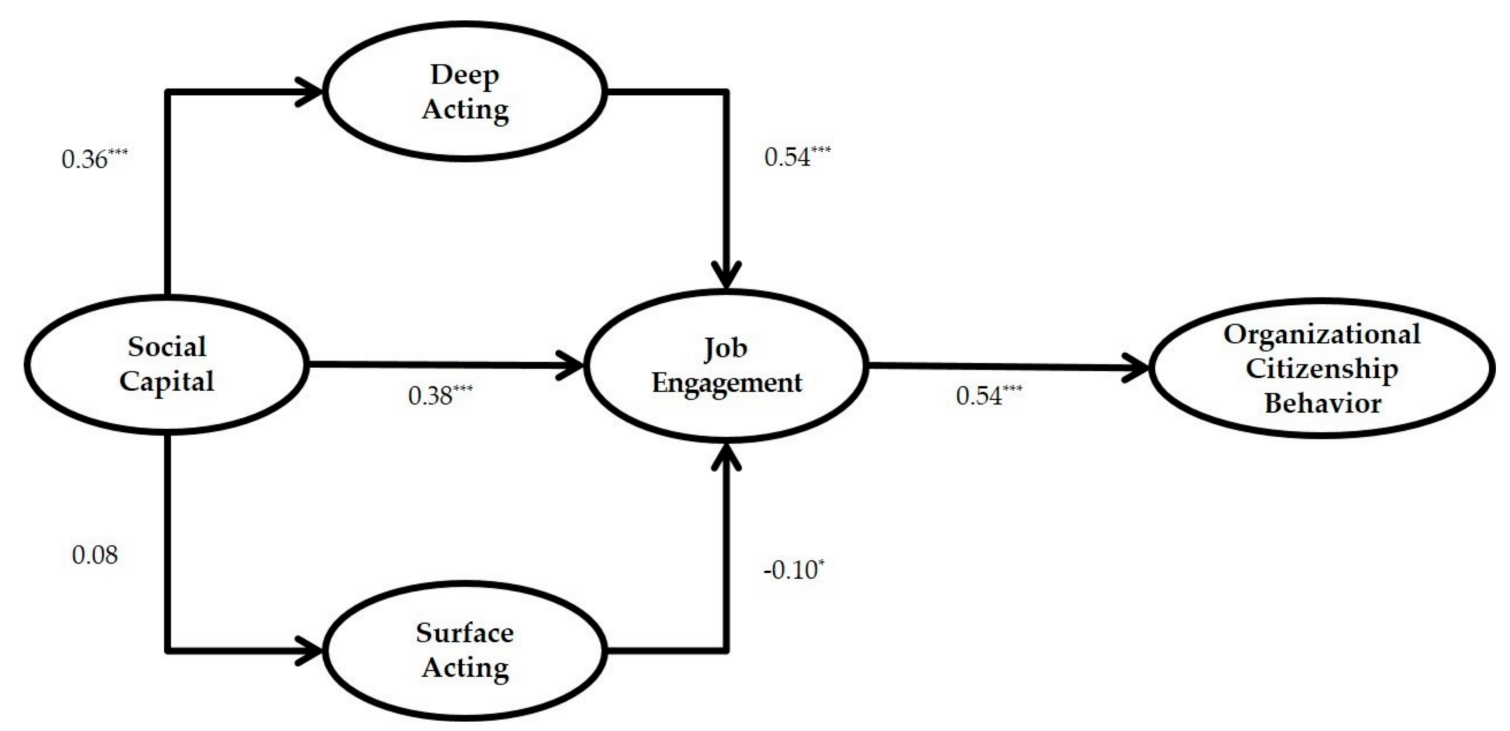

Figure 1. Structural model results. Note: $N=330 ;{ }^{*} p<0.05 ;{ }^{* *} p<0.01 ;{ }^{* * *} p<0.001$. 
Table 2. Indirect effects for the double-mediation effects (deep acting and job engagement).

\begin{tabular}{llll}
\hline \multirow{2}{*}{ From $\rightarrow$ To } & \multicolumn{3}{l}{ Indirect Effects } \\
\cline { 2 - 4 } & Estimate & $\mathbf{C I}_{\text {low }}$ & $\mathbf{C I}_{\text {high }}$ \\
\hline Total indirect effect & $0.16(0.03)$ & 0.10 & 0.22 \\
$\mathrm{SC} \rightarrow \mathrm{DA} \rightarrow$ OCB & $0.08(0.02)$ & 0.04 & 0.14 \\
$\mathrm{SC} \rightarrow \mathrm{JE} \rightarrow$ OCB & $0.04(0.01)$ & 0.01 & 0.07 \\
$\mathrm{SC} \rightarrow \mathrm{DA} \rightarrow \mathrm{JE} \rightarrow$ OCB & $0.03(0.01)$ & 0.01 & 0.05 \\
\hline
\end{tabular}

Note. $N=330$; Bootstrap confidence intervals (CIs) were constructed using 5000 resamples; Total effect (SC $\rightarrow$ $\mathrm{OCB})=0.57(0.03)^{* * *}$; Standard errors in parentheses; $\mathrm{SC}=$ social capital; DA = deep acting; JE = job engagement; $\mathrm{OCB}=$ organizational citizenship behavior.

Table 3. Indirect effects for the double-mediation effects (surface acting and job engagement).

\begin{tabular}{llll}
\hline \multirow{2}{*}{ From $\rightarrow$ To } & \multicolumn{3}{l}{ Indirect Effects } \\
\cline { 2 - 4 } & Estimate & $\mathbf{C I}_{\text {low }}$ & $\mathbf{C I}_{\text {high }}$ \\
\hline Total indirect effect & $0.12(0.02)$ & 0.07 & 0.18 \\
$\mathrm{SC} \rightarrow \mathrm{SA} \rightarrow$ OCB & $0.00(0.00)$ & 0.00 & 0.01 \\
$\mathrm{SC} \rightarrow \mathrm{JE} \rightarrow$ OCB & $0.12(0.02)$ & 0.07 & 0.17 \\
$\mathrm{SC} \rightarrow \mathrm{SA} \rightarrow \mathrm{JE} \rightarrow$ OCB & $0.00(0.00)$ & 0.00 & 0.00 \\
\hline
\end{tabular}

Note. $N=330$; Bootstrap confidence intervals (CIs) were constructed using 5000 resamples; Total effect (SC $\rightarrow$ $\mathrm{OCB})=0.57(0.03)^{* * *} ;$ Standard errors in parentheses; $\mathrm{SC}=$ social capital; SA = surface acting; JE = job engagement; $\mathrm{OCB}=$ organizational citizenship behavior.

Table 3 shows that that surface acting did not mediate the link between social capital and OCB (indirect effect $=0.00, \mathrm{SE}=0.00, \mathrm{CI}=[0.00,0.01]$ ), whereas job engagement was a significant mediator (indirect effect $=0.12, \mathrm{SE}=0.02, \mathrm{CI}=[0.07,0.17]$ ). Finally, the link between social capital and OCB was not sequentially mediated by surface acting and job engagement (indirect effect $=0.00, \mathrm{SE}=0.00$, $\mathrm{CI}=[0.00,0.00])$, thus rejecting Hypothesis 8 .

\section{Discussion}

We examined the impact of social capital on OCB in the emotional labor context. We theorized and empirically tested the double-mediation effects of emotional regulation and job engagement. The results demonstrate that employees with strong social capital perform more OCB sequentially through deep acting and higher job engagement. Social capital did not predict the use of surface acting. Moreover, surface acting and job engagement did not sequentially mediate the social capital-OCB link, either. While social capital facilitates employees' deep acting during service encounters, it does not seem to discourage surface acting.

\subsection{Implications}

This study adds to the knowledge on emotional labor in several ways. First, we introduce social capital as a key antecedent of emotional regulation strategies. By extending prior emotional labor studies, we examine a wide range of the antecedents for emotional regulation strategies $[18,20$,25-27]. Our study provides empirical evidence showing that strong social capital facilitates deep acting, which is deemed more beneficial for employees and organizations $[23,24]$. In addition, given the importance of social capital in employees' organizational lives [2,62], our findings offer a fruitful way forward for the literature on emotional labor.

Second, we contribute to the literature on emotional labor by examining service employees' OCB as an extra-role performance. Although OCB may not be the best indicator of service employees' performance, being a contextual performance, it is as important as task performance [3]. While the importance of OCB is well acknowledged in the literature $[11,37,38]$, emotional labor scholars have paid scant attention to it except for a few [35,36]. A recent meta-analysis [23] showed that focal performance outcomes of emotional regulation have been customer satisfaction and emotional and 
task performance, but not contextual performance. By revealing how social capital energizes sales employees' $\mathrm{OCB}$, we provide empirical evidence of contextual performance in the emotional labor context, thus deepening our understanding of $\mathrm{OCB}$ and advancing the literature.

Third, our findings offer an explanation of how job resources can lead to extra-role performance by demonstrating that deep acting and job engagement sequentially mediate the positive link between social capital and OCB. It is noteworthy that most prior studies on emotional labor mainly explored employees' psychological well-being or stress as mediators (e.g., [19,31,39,45,46]). Although Yoo and Arnold [31] explicitly incorporated emotional labor aspect in their model, they focused on the mechanism of how job resources lead to one's choice of emotional labor strategies through a customer-oriented attitude. Our study expands on the current literature on emotional labor by incorporating both emotional regulation strategies and a psychological variable (i.e., job engagement) as double mediators, thus enriching our understanding of emotional labor.

Finally, our study advances the literature on the JD-R model by considering social capital as a job resource. Knowledge, information, and support acquired through social relationships on the job help employees fulfill their job requirements and achieve their performance goals $[7,62]$. In the emotional labor context, service employees with strong social capital may be better informed of the rules of emotional display and of ways to improve service performance. Our approach offers a new insight into the role of social capital as a job resource.

We also advance the literature on JD-R by emphasizing its motivational processes (i.e., job engagement) and positive outcomes such as OCB. Unlike prior studies grounded on the JD-R model with a focus on negative outcomes (e.g., burnout [29,30], strains [42], in-role performance [29], or absenteeism and turnover [39]), we highlight the importance of job resources [28] in producing positive motivational states as well as proactive contextual performance $[29,90]$. Therefore, our study suggests a fruitful way to advance the JD-R model by exclusively highlighting the positive psychological processes and outcomes.

Our findings provide important implications for organizations seeking to establish sustainable workplaces, especially those in the service industry where emotional labor demands are high. Since deep acting is generally deemed more valuable in the emotional labor context, it is important for organizations to energize their emotions in increasing deep acting. Our findings indicate that social capital provides service employees with sufficient resources to engage in deep acting, and even increases their extra-role performance by energizing their motivational states. Hence, to cultivate a sustainable workplace, it is imperative for organizations to help employees build strong social capital. One way is to provide service employees with various opportunities to connect with other members of the organization. For example, organizations may provide new employees with institutionalized socialization experiences so that they can build strong social capital upon organizational entry [62]. In addition, organizations may use a job or organization design (i.e., matrix structure, cross-functional teams, etc.) that helps successfully embed employees in the informal social structure of the organization [100].

\subsection{Limitations and Future Study Avenues}

This study has a few limitations. First, because we used single-sourced data, we are not able to completely rule out the common method variance (CMV) as a possible alternative explanation for our results. Given the nature of our constructs, using self-reports was inevitable. Although the Harman's single-factor test results suggest that our results do not have serious common method bias, there is a concern that employees may have over-reported their own OCB to make favorable impressions. A recent meta-analysis [101] showed, however, that the mean differences between self-rated and other-rated OCB is negligibly small, indicating that self-report is a viable way to measure OCB. Similarly, a meta-analysis [102] also showed that, despite some skepticism on the self-reports of counterproductive work behavior (CWB), which is also an example of employees' contextual behaviors, 
it is still a viable alternative to the other reports. However, to rule out any potential issues, future research replicating our findings using multi-sourced data can help further our findings.

Second, for the purpose of our study, we measured only the extra-role performance of service employees. Although contextual performance is important, we acknowledge that in-role performance of service employees can be very important for building sustainable workplaces. Thus, future studies should incorporate the in-role performance as a focal variable and examine if our arguments still hold for other dimensions of employee performance.

Third, our study used cross-sectional design, which potentially raises uncertainty about the causality among the variables included in our hypotheses model. Therefore, future studies should validate the findings of our study by using longitudinal designs so that it offers more robust evidence of the link between social capital and OCB. Furthermore, much would be obtained by future research if an experience sampling methodology (ESM) was used for measuring emotional regulation over time.

Fourth, our study identified emotional regulation and job engagement as a mediating mechanism by which employee's social capital influences his or her OCB. Yet, the moderators that accentuate or attenuate the link between social capital and OCB were not included in out model. Thus, future studies should include moderators such as personal resources (e.g., emotional intelligence and self-efficacy) and organizational resources (e.g., supervisor or organizational support) that fluctuate the relationship among variables.

Fifth, while our study theorized and tested how social capital influences OCB, several prior studies suggest social capital as a consequence of OCB (e.g., [103]). The acts of OCB indeed have potential to cultivate and maintain social capital when the effects accumulate over time. Future studies may adopt a longitudinal approach and examine the reciprocal relationships between social capital and OCB. Additional interesting research avenue would be to reveal how social capital and OCB mutually reinforce each other to enhance organizational performance and contribute to organizational sustainability.

Finally, our study focused on employees selling financial or insurance products in South Korea. Future studies which involve larger sample of employees across industries and nations would usefully validate our findings.

Author Contributions: S.-H.K. wrote the first draft of this manuscript and designed the model used in the study. Y.C. designed the methodology part, conducted and analyzed the empirical test results. S.-Y.R. and T.W.M. supplemented several parts of the paper and refined the entire article. S.-Y.R. interpreted the theoretical implications and T.W.M. evaluated the practical implications of our findings. All authors contributed to writing this manuscript.

Funding: For Yongjun Choi, this work was supported by the Hongik University new faculty research support fund.

Conflicts of Interest: There are no conflicts of interest to declare.

\section{References}

1. Burt, R.S. The contingent value of social capital. Admin. Sci. Q. 1997, 42, 339-365. [CrossRef]

2. Fang, R.; Landis, B.; Zhang, Z.; Anderson, M.V.; Shaw, J.D.; Kilduff, M. Integrating personality and social networks: A meta-analysis of personality, network position, and work outcomes in organizations. Organ. Sci. 2015, 26, 1243-1260. [CrossRef]

3. Borman, W.; Motowildo, S. Task performance and contextual performance: The meaning for personnel selection research. Hum. Perform. 1997, 10, 99-109. [CrossRef]

4. Adler, P.S.; Kwon, S.-W. Social capital: Prospects for a new concept. Acad. Manag. Rev. 2002, 24, 17-40. [CrossRef]

5. Brass, D.J.; Galaskiewicz, J.; Greve, H.R.; Tsai, W. Taking stock of networks and organizations: A multiple perspective. Acad. Manag. J. 2004, 47, 795-817. [CrossRef]

6. Kouvonen, A.; Kivimäki, M.; Vahtera, J.; Oksanen, T.; Elovaino, M.; Cox, T.; Virtanen, M.; Pentti, J.; Cox, S.J.; Wilkinson, R.G. Psychometric evaluation of a short measure of social capital at work. BMC Public Health 2006, 6, 251-261. [CrossRef] [PubMed] 
7. Tsai, W.; Ghoshal, S. Social capital and value creation: The role of intrafirm networks. Acad. Manag. J. 1998, 41, 464-476. [CrossRef]

8. Yang, J.; Gong, Y.; Huo, Y. Proactive personality, social capital, helping, and turnover intentions. J. Manag. Psychol. 2011, 26, 739-760. [CrossRef]

9. Bowler, W.M.; Brass, D.J. Relational correlates of interpersonal citizenship behavior: A social network perspective. J. Appl. Psychol. 2006, 91, 70-82. [CrossRef] [PubMed]

10. Venkataramani, V.; Dalal, R.S. Who helps and harms whom? Relational antecedents of interpersonal helping and harming in organizations. J. Appl. Psychol. 2007, 92, 925-966. [CrossRef] [PubMed]

11. Wang, T.; Heng, Q.; Lu, Y.; Yang, D. How does organizational citizenship behavior (OCB) affect the performance of megaprojects? Insights from a system dynamic simulation. Sustainability 2018, 10, 1708. [CrossRef]

12. Johns, G. The essential impact of context on organizational behavior. Acad. Manag. J. 2006, 31, $386-408$. [CrossRef]

13. Ashforth, B.E.; Humphrey, R.H. Emotional labor in service roles: The influence of identity. Acad. Manag. Rev. 1993, 18, 88-115. [CrossRef]

14. Allen, J.A.; Pugh, S.D.; Grandey, A.A.; Groth, M. Following display rules in good or bad faith? Customer orientation as a moderator of the display rule-emotional labor relationship. Hum. Perform. 2010, 23, 101-115. [CrossRef]

15. Christoforou, P.S.; Ashforth, B.E. Revisiting the debate on the relationship between display rules and performance: Considering the explicitness of display rules. J. Appl. Psychol. 2015, 100, 249-261. [CrossRef] [PubMed]

16. Rafaeli, A.; Sutton, R.I. Expression of emotions as part of the work role. Acad. Manag. Rev. 1987, 12, $23-37$. [CrossRef]

17. Sutton, R.I. Maintaining norms about expressed emotions: The case of bill collectors. Admin. Sci. Q. 1991, 36, 245-268. [CrossRef]

18. Grandey, A.A. When "The show must go on": Surface acting and deep acting as determinants of emotional exhaustion and peer-rated service delivery. Acad. Manag. J. 2003, 46, 86-96. [CrossRef]

19. Hur, W.-M.; Moon, T.W.; Han, S.-J. The effect of customer incivility on service employees' customer orientation through double-mediation of surface acting and emotional exhaustion. J. Serv. Theor. Pract. 2015, 25, 394-413. [CrossRef]

20. Kong, H.; Jeon, J.-E. Daily emotional labor, negative affect state, and emotional exhaustion: Cross-level moderators of affective commitment. Sustainability 2018, 10, 1967. [CrossRef]

21. Zablah, A.R.; Franke, G.R.; Brown, T.J.; Bartholomew, D.E. How and when does customer orientation influence frontline employee job outcomes? A meta-analysis evaluation. J. Mark. 2012, 76, 21-40. [CrossRef]

22. Ha, S. Surface acting and job-related affective wellbeing: Preventing resource loss spiral and resource loss cycle for sustainable workplaces. Sustainability 2018, 10, 1099. [CrossRef]

23. Hülsheger, U.R.; Schewe, A.F. On the costs and benefits of emotional labor: A meta-analysis of three decades of research. J. Occup. Health Psych. 2011, 16, 361-389. [CrossRef] [PubMed]

24. Kammeyer-Mueller, J.D.; Rubenstein, A.L.; Long, D.M.; Odio, M.A.; Buckman, B.R.; Zhang, Y.; Halvorsen-Ganepola, M.D.K. A meta-analytic structural model of dispositional affectivity and emotional labor. Pers. Psychol. 2013, 66, 47-90. [CrossRef]

25. Brotheridge, C.M.; Grandey, A.A. Emotional labor and burnout: Comparing two perspectives of "people work". J. Vocat. Behav. 2002, 60, 17-39. [CrossRef]

26. Brotheridge, C.M.; Lee, R.T. Testing a conservation of resources model of the dynamics of emotional labor. J. Occup. Health Psych. 2002, 7, 57-67. [CrossRef]

27. Diefendorff, J.M.; Croyle, M.H.; Gosserand, R.H. The dimensionality and antecedents of emotional labor strategies. J. Vocat. Behav. 2005, 66, 339-357. [CrossRef]

28. Bakker, A.N.; Demerouti, E. The job demands-resources model: State of art. J. Manag. Psychol. 2007, 22, 309-328. [CrossRef]

29. Bakker, A.B.; Demerouti, E.; Verbeke, W. Using the job demands-resources model to predict burnout and performance. Hum. Resour. Manag. 2004, 43, 83-104. [CrossRef]

30. Demerouti, E.; Bakker, A.B.; Nachreiner, F.; Schaufeli, W.B. The job demands-resources model of burnout. J. Appl. Psychol. 2001, 86, 499-512. [CrossRef] [PubMed] 
31. Yoo, J.; Arnold, T.J. Frontline employee customer-oriented attitude in the presence of job demands and resources: The influence upon deep and surface acting. J. Serv. Res. 2016, 19, 102-117. [CrossRef]

32. Fagerlind, A.-C.; Gustavsson, M.; Johansson, G.; Ekberg, K. Experience of work-related flow: Does high decision latitude enhance benefits gained from job resources? J. Vocat. Behav. 2013, 83, 161-170. [CrossRef]

33. Felício, J.A.; Couto, E.; Caiado, J. Human capital, social capital and organizational performance. Manag. Decis. 2014, 52, 350-364. [CrossRef]

34. Gilbert, K.L.; Quinn, S.C.; Goodman, R.M.; Butler, J.; Wallace, J. A meta-analysis of social capital and health: A case for needed research. J. Health Psychol. 2013, 18, 1385-1399. [CrossRef] [PubMed]

35. Bettencourt, L.A.; Gwinner, K.P.; Meuter, M.L. A comparison of attitude, personality, and knowledge predictors of service-oriented organizational citizenship behaviors. J. Appl. Psychol. 2001, 86, $29-41$. [CrossRef] [PubMed]

36. Salami, S.O. Moderating effect of emotional intelligence on the relationship between emotional labor and organizational citizenship behavior. Eur. J. Soc. Sci. 2007, 5, 142-150.

37. LePine, J.A.; Erez, A.; Johnson, D.E. The nature and dimensionality of organizational citizenship behavior: A critical review and meta-analysis. J. Appl. Psychol. 2002, 87, 52-65. [CrossRef] [PubMed]

38. Podsakoff, N.P.; Whiting, S.W.; Podsakoff, P.M.; Blume, B.D. Individual- and organizational-level consequences of organizational citizenship behaviors: A meta-analysis. J. Appl. Psychol. 2009, 94, 122-141. [CrossRef] [PubMed]

39. Bakker, A.; Demerouti, E.; Schaufeli, W. Dual processes at work in a call center: An application of job demands-resources model. Eur. J. Work. Organ. Psychol. 2003, 12, 393-417. [CrossRef]

40. Hakanen, J.J.; Schaufeli, W.B.; Ahola, K. The job demands-resources model: A three-year cross-lagged study of burnout, depression, commitment, and work engagement. Work Stress 2008, 22, 224-241. [CrossRef]

41. Hobfoll, S.E. Conservation of resources: A new attempt at conceptualizing stress. Am. Psychol. 1989, 44, 513-524. [CrossRef] [PubMed]

42. Demerouti, E.; Bakker, A.B. The job demands-resources model: Challenges for future research. SA J. Ind. Psychol. 2011, 37, 1-9. [CrossRef]

43. Fernet, C.; Austin, S.; Vallerand, R.J. The effects of work motivation on employee exhaustion and commitment: An extension of the JD-R model. Work Stress 2012, 46, 213-229. [CrossRef]

44. Hobfoll, S.E.; Halbesleben, J.; Neveu, J.-P.; Westman, M. Conservation resources in the organizational context: The reality of resources and their consequences. Annu. Rev. Organ. Psychol. Organ. Behav. 2018, 5, 103-128. [CrossRef]

45. Van Gelderen, B.; Heuvenm, E.; Van Veldhoven, M.; Zeelenberg, M.; Croon, M. Psychological strain and emotional labor among police-officers: A dairy study. J. Vocat. Behav. 2007, 71, 446-459. [CrossRef]

46. Lee, R.T.; Lovell, B.L.; Brotheridge, C.M. Tenderness and steadiness: Relating job and interpersonal demands and resources with burnout and physical symptoms of stress in Canadian physicians. J. Appl. Soc. Psychol. 2010, 49, 2319-2342. [CrossRef]

47. Westman, M.; Hobfoll, S.E.; Chen, S.; Davidson, O.B.; Laski, S. Organizational stress through the lens of Conservation of Resources (COR) theory. In Research in Occupational Stress and Well-Being; Perrewe, P.L., Ganster, D.C., Eds.; JAI Press: Amsterdam, The Netherlands, 2005; Volume 4, pp. 167-220.

48. Demerouti, E.; Cropanzano, R.R. From thought to action: Employee work engagement and job performance. In Work Engagement: A Handbook of Essential Theory and Research; Bakker, A.B., Leiter, M.P., Eds.; Psychology Press: New York, NY, USA, 2010; pp. 147-163.

49. Grandey, A.A.; Fisk, G.M.; Steiner, D.D. Must "Service with a smile" be stressful? The moderating role of personal control for Americans and French employees. J. Appl. Psychol. 2005, 90, 893-904. [CrossRef] [PubMed]

50. Grandey, A.A.; Foo, S.C.; Groth, M.; Goodwin, R.E. Free to be you and me: Climate of authenticity alleviates burnout from emotional labor. J. Occup. Health Psych. 2012, 17, 1-14. [CrossRef] [PubMed]

51. Uy, M.A.; Lin, K.J.; Illies, R. Is it better to give or receive? The role of help in buffering the depleting effects of surface acting. Acad. Manag. J. 2017, 60, 1442-1461. [CrossRef]

52. Ozcelik, H. An empirical analysis of surface acting in intra-organizational relationships. J. Organ. Behav. 2013, 34, 291-309. [CrossRef]

53. Chau, S.L.; Dahling, J.J.; Levy, P.E.; Diefendorff, J.M. A predictive study of emotional labor and turnover. J. Organ. Behav. 2009, 30, 1151-1163. [CrossRef] 
54. Shanock, L.R.; Allen, J.A.; Dunn, A.M.; Baran, B.E.; Scott, C.W.; Rogelberg, S.G. Less acting, more doing: How surface acting relates to perceived meeting effectiveness and other employee outcomes. J. Occup. Organ. Psychol. 2013, 86, 457-476. [CrossRef]

55. Totterdell, P.; Homan, D. Emotion regulation in customer service roles: Testing a model of emotional labor. J. Occup. Health Psychol. 2003, 8, 55-73. [CrossRef] [PubMed]

56. Wrzesniewski, A.; Dutton, J. Crafting a job: Employees as active crafters of their work. Acad. Manag. Rev. 2001, 26, 179-201. [CrossRef]

57. Lee, J.H.; Ok, C. Reducing burnout and enhancing job satisfaction: Critical role of hotel employees' emotional intelligence and emotional labor. Int. J. Hosp. Manag. 2012, 31, 1101-1112. [CrossRef]

58. Liu, Y.; Prati, L.M.; Perrewé, P.L.; Ferris, G.R. The relationship between emotional resources and emotional labor: An exploratory study. J. Appl. Soc. Psychol. 2008, 38, 2410-2439. [CrossRef]

59. Coleman, J.S. Social capital in the creation of human capital. Am. J. Sociol. 1988, 94, S95-S120. [CrossRef]

60. Brehm, J.; Rahn, W. Individual-level evidence for the causes and consequences of social capital. Am. J. Political Sci. 1997, 41, 999-1023. [CrossRef]

61. Nahapiet, J.; Ghoshal, S. Social capital, intellectual capital, and the organizational advantage. Acad. Manag. Rev. 1998, 18, 242-266. [CrossRef]

62. Fang, R.; Duffy, M.K.; Shaw, J.D. The organizational socialization process: Review and development of a social capital model. J. Manag. 2011, 37, 127-152. [CrossRef]

63. Kelman, H.C. Compliance, identification, and internalization three processes of attitude change. J. Confl. Resolut. 1958, 2, 51-60. [CrossRef]

64. Ashforth, B.E.; Mael, F. Social identity theory and the organization. Acad. Manag. Rev. 1989, 14, 20-39. [CrossRef]

65. Schaufeli, W.B.; Salanova, M.; González-romá, V.; Bakker, A.B. The measurement of engagement and burnout: A two sample confirmatory factor analytic approach. J. Happiness Stud. 2002, 3, 71-92. [CrossRef]

66. Kahn, W.A. Psychological conditions of personal engagement and disengagement at work. Acad. Manag. J. 1990, 33, 692-724. [CrossRef]

67. Nahrgang, J.D.; Morgeson, F.P.; Hoffmann, D.A. Safety at work: A meta-analytic investigation of the link between job demands, job resources, burnout, engagement, and safety outcomes. J. Appl. Psychol. 2011, 96, 71-94. [CrossRef] [PubMed]

68. Van den Broeck, A.; De Cuyper, N.; De Witte, H.; Vansteenkiste, M. Not all job demands are equal: Differentiating job hindrance and job challenges in the job demands-resources model. Eur. J. Work Organ. Psy. 2010, 19, 735-759. [CrossRef]

69. Mauno, S.; Kinnunen, U.; Ruokolainen, M. Job demands and resources and antecedents of work engagement. J. Vocat. Behav. 2007, 70, 149-171. [CrossRef]

70. Cohen, S.; Syme, S.L. Social Support and Health; Academic Press: San Diego, CA, USA, 1985.

71. Seibert, S.E.; Kraimer, M.L.; Liden, R.C. A social capital theory of career success. Acad. Manag. J. 2001, 44, 219-237. [CrossRef]

72. Eisenberger, R.; Huntington, R.; Hutchison, S.; Sowa, D. Perceived organizational support. J. Appl. Psychol. 1986, 71, 500-507. [CrossRef]

73. Eisenberger, R.; Fasolo, P.; Davis-LaMastro, V. Perceived organizational support and employee diligence, commitment, and innovation. J. Appl. Psychol. 1990, 75, 51-59. [CrossRef]

74. Wharton, A.S. The affective consequences of service work. Work Occup. 1993, 20, 205-232. [CrossRef]

75. Bechtoldt, M.J.; Rohrmann, S.; De Pater, I.E.; Beersma, B. The primacy of perceiving: Emotion recognition buffers negative effects of emotional labor. J. Appl. Psychol. 2011, 96, 1087-1094. [CrossRef] [PubMed]

76. May, D.R.; Gilson, R.L.; Harter, L.M. The psychological conditions of meaningfulness, safety, and availability and the engagement of the human spirits at work. J. Occup. Organ. Psych. 2004, 77, 11-37. [CrossRef]

77. Grandey, A.A.; Fisk, G.M.; Mattila, A.S.; Jansen, K.J.; Sideman, L.A. Is "service with a smile" enough? Authenticity of positive displays during service encounters. Organ. Behav. Hum. Dec. 2006, 96, 38-88. [CrossRef]

78. Lu, X.; Guy, M.E. How emotional labor and ethical leadership affect job engagement for Chinese public servants. Public Pers. Manag. 2014, 43, 3-24. [CrossRef]

79. Organ, D.W. Organizational Citizenship Behavior: The Good Soldier Syndrome; Lexington Books: Lexington, MA, USA, 1988. 
80. Van Dyne, L.; Graham, J.W.; Dienesch, R.M. Organizational citizenship behavior: Construct redefinition, measurement, and validation. Acad. Manag. J. 1994, 67, 765-802. [CrossRef]

81. Tepper, B.J.; Taylor, E.C. Relationships among supervisors' subordinates' procedural justice perceptions and organizational citizenship behaviors. Acad. Manag. J. 2003, 46, 97-105. [CrossRef]

82. Towers-Perrin. The 2003 Towers-Perrin Talent Report: Working Today: Understanding What Drives Employee Engagement; Towers-Perrin: Stamford, CT, USA, 2003.

83. Macey, W.H.; Schneider, B. The meaning of employee engagement. Ind. Organ. Psychol. 2008, 1, 3-30. [CrossRef]

84. Kahn, W.A. To be full there: Psychological presence at work. Hum. Relat. 1992, 45, 321-349. [CrossRef]

85. Avey, J.B.; Wernsing, T.S.; Luthans, F. Can positive employees help positive organizational change? Impact of psychological capital and emotions on relevant attitudes and behaviors. J. Appl. Behav. Sci. 2008, 44, 48-70. [CrossRef]

86. Babcock-Roberson, M.E.; Strickland, O.J. The relationship between charismatic leadership, work engagement, and organizational citizenship behavior. J. Psychol. 2010, 144, 313-326. [CrossRef] [PubMed]

87. Christian, M.S.; Garza, A.S.; Slaughter, J.E. Work engagement: A quantitative review and test of its relations with task and conceptual performance. Pers. Psychol. 2011, 64, 89-136. [CrossRef]

88. Rich, B.L.; Lepine, J.A.; Crawford, E.R. Job engagement: Antecedents and effects on job performance. Acad. Manag. J. 2010, 53, 617-635. [CrossRef]

89. Rurhkhum, S.; Bartlett, K.R. The relationship between employee engagement and organizational citizenship behavior in Thailand. Hum. Resour. Dev. Int. 2012, 15, 157-174. [CrossRef]

90. Bakker, A.B.; Demerouti, E. Towards a model of work engagement. Career Dev. Int. 2008, 13, $209-223$. [CrossRef]

91. Brislin, R.W. Translation and content analysis of oral and written material. In Handbook of Cross-Cultural Psychology; Triandis, H.C., Berry, J.W., Eds.; Allyn \& Bacon: Boston, MA, USA, 1980; pp. 389-444.

92. Biong, H.; Ulvnes, A.M. If the supplier's human capital walks away, where would the customer go? J. Bus.-Bus. Mark. 2011, 18, 233-252. [CrossRef]

93. Schaufeli, W.B.; Bakker, A.B.; Salanova, M. The measurement of work engagement with a short questionnaire. Educ. Psychol. Meas. 2006, 66, 701-716. [CrossRef]

94. Niehoff, B.P.; Moorman, R.H. Justice as moderator of the relationship between methods of monitoring and organizational citizenship behavior. Acad. Manag. J. 1993, 36, 527-556. [CrossRef]

95. Nunnally, J.C. Psychometric Theory, 2nd ed.; McGraw-Hill: New York, USA, 1978.

96. Fornell, C.; Larcker, D.F. Evaluating structural equation models with unobservable variables and measurement error. J. Mark. Res. 1981, 18, 39-50. [CrossRef]

97. Podsakoff, P.M.; MacKenzie, S.B.; Lee, J.; Podsakoff, N.P. Common method biases in behavioral research: A critical review of the literature and recommended remedies. J. Appl. Psychol. 2003, 88, 879-903. [CrossRef] [PubMed]

98. Shrout, P.E.; Bolger, M. Mediation in experimental and nonexperimental studies: New procedures and recommendations. Psychol. Methods 2002, 7, 422-445. [CrossRef] [PubMed]

99. Preacher, K.J.; Hayes, A.F. Asymptotic and resampling strategies for assessing and comparing indirect effects in multiple mediator models. Behav. Res. Methods 2008, 40, 879-891. [CrossRef] [PubMed]

100. Kilduff, M.; Brass, D.J. Job design: A social network perspective. J. Organ. Behav. 2010, 31, 309-318. [CrossRef]

101. Carpenter, N.C.; Berry, C.B.; Houston, L. A meta-analytic comparison of self-reported and other-reported organizational citizenship behavior. J. Organ. Behav. 2014, 35, 547-574. [CrossRef]

102. Berry, C.M.; Carpenter, N.C.; Barrat, C.L. Do other-reports of counterproductive work behavior provide an incremental contribution over self-reports? A meta-analytic comparison. J. Appl. Psychol. 2012, 97, 613-636. [CrossRef] [PubMed]

103. Bolino, M.C.; Turnley, W.H.; Bloodgood, J.M. Citizenship behavior and the creation of social capital in organizations. Acad. Manag. Rev. 2002, 27, 505-522. [CrossRef]

(C) 2018 by the authors. Licensee MDPI, Basel, Switzerland. This article is an open access article distributed under the terms and conditions of the Creative Commons Attribution (CC BY) license (http:/ / creativecommons.org/licenses/by/4.0/). 